\title{
ИСКЛЮЧЕНИЕ ИСПОЛЬЗОВАНИЯ НАРКОТИЧЕСКИХ СРЕДСТВ И ДОПИНГА В МЕЖДУНАРОДНОМ СПОРТИВНОМ ДВИЖЕНИИ
}

\begin{abstract}
Аннотация. В статье рассматривается вопрос использования наркотических средств и допинга в международном спортивном движении. Автор констатирует что в настоящее время на всех континентах созданы специальные лаборатории, осуществляющие анализ проб на употребление допинга. Долгое время МОК и несколько международных спортивных федераций оставались единственными из международных спортивных организаций, кто вел борьбу с допингом в спорте.Рассматривается вопрос создания в специальных международных и национальных органов по борьбе с допингом. Исследуется деятельность Всемирного антидопингового агентства. Приводиться ряд выявленных фактов употребления допинга $u$ дается их юридическая характеристика. Автором используются классические методы исследования. В том числе сравнительно-правовой метод. Исследуется ряд документов международно-правового характера, а также российское законодательство о применении допинга в спорте. Автор считает, что нет оснований заимствовать правовые предписания Спортивного кодекса Франции или франиузскую модель кодификации законодательства о спорте в неизменном виде, но учесть положительный франиузский опыт при совершенствовании и кодификации отечественного законодательства о спорте вполне целесообразно.
\end{abstract}

Ключевые слова: международное спортивное движение, допинг, наркомания, психотропные вещества, прекурсоры, лекарственные препараты, олимпийское движение, уголовная ответственность, спортсмен, тренер Abstract: The article concerns the issue of use of narcotic and performance enhancing substances (doping) in the international sports movement. The author states that currently in all continents there are special laboratories providing analysis of samples for establishing presence of performance enhancing drugs. For a long time the IOC and several international sports federation remained the only ones among the international sports organizations fighting performance enhancing drugs in sports. The author discusses the issue of formation of special international and national bodies for fighting use of performance enhancing drugs. The author also studies the activities of the World Anti-Doping Agency. The author analyzes a number offacts concerning the use of performance enhancing substances an provides their legal characteristics. The author uses classical study methods, including comparative legal method, studying a number of international legal documents and the Russian legislation concerning use of doping in sports. The author considers that there is no grounds for adopting the legal provisions of the Sports Code of France or the French model of codification of sports legislation as a whole, while it may be viable to use positive French experience in the process of improvement and codification of the Russian legislation. Keywords: international sports movement, doping, narcotic addiction, psychoactive substances, precursors, medications, the Olympic movement, criminal responsibility, sportsman, trainer.

опинг в спорте - это запрещенные фармакологические препараты, методы и процедуры, используемые с целью стимуляции физическом и психической работоспособности и достижения благодаря этому высокого спортивного результата.

Согласно решению Международного олимпийского комитета к допингам относятся:

1) так называемые допинговые вещества, которые разделены на пять групп:

- анаболические стероиды (тестостерон, ретаболил, метенол и др.);
- бета-блокаторы (пропланолол, атенолол, метропролол и др.);

- диуретические средства (дихлотиозид, гидрохлотиазидфуресеросемид и др.);

- стимуляторы (амфетамин, кофеин, кокаин, эфедрин, метил- эфедрин, фентермин и др.);

- наркотические средства (кодеин, героин, морфин и др.);

2) допинговые методы, например кровяной допинг аутогемотрансфузия, использование эритропоэтина, препаратов, увеличивающих плазму крови; 
3) вещества, прием которых на соревнованиях подлежит ограничению и в случае отсутствия прямых медицинских показаний также может быть расценен как допинг.

В 1865 г. во время соревнований по плаванию в Амстердаме впервые было употреблено слово «допинг» по отношению к спортсменам, пользовавшимся стимуляторами. С тех пор оно и закрепилось в сфере спорта. Первая смерть от допинга была зафиксирована в 1886 г. на соревнованиях по велосипедному спорту. В начале XX в. Применение различных стимуляторов получило широкое распространение.

Игры XV11 Олимпиады (1960 г., Рим, Италия омрачены трагедией: во время соревнований по велосипедному спорту скончался от перенапряжения датчанин К. Йенсен. Это был первый тревожный сигнал проникновения допинга на Олимпийские игры.

Впервые вопрос, связанный с применением допинга в спорте, был поднят в 1960 г. на Международном конгрессе по психофизиологии. Первой спортивной организацией, которая начала действенную борьбу против применения допинга был Международный олимпийский комитет. В 1962 г. сессия МОК в Москве дала рекомендации относительно запрещения приема допингов. В 1967 г. Международный олимпийский, комитет принял решение о запрещении допинга в спорте. Начиная с Игр XIX Олимпиады (1968 г., Мехико) специально созданной при МОК Медицинской комиссией стал проводиться допинг-контроль. Комиссия была образована в 1967 г.

На ХIX Олимпийских играх был проведен выборочный допинг- контроль, а с 1972 г. (Мюнхен) он стал обязателен во всех видах олимпийской программы, а впоследствии и на чемпионатах мира и континентов по большинству видов спорта, что предусмотрено уставом МОК и международных спортивных федераций.

В настоящее время на всех континентах созданы специальные лаборатории, осуществляющие анализ проб на употребление допинга. Долгое время МОК и несколько международных спортивных федераций оставались единственными из международ- ных спортивных организаций, кто вел борьбу с «чумой XX века».

На Играх XXIV Олимпиады (1988 г., Сеул, Южная Корея) было зафиксировано 10 случаев употребления допинга. Весь мир узнал, что дисквалифицирован один из самых знаменитых спортсменов мира - канадский спринтер Бен Джонсон, установивший накануне феноменальный мировой рекорд в беге на 100 м 9,79. После этой Олимпиады все международные спортивные федерации и национальные олимпийские комитеты подключились к борьбе с допингом.

К сожалению, неприятность произошла и с нашей известной спортсменкой, шестикратной олимпийской чемпионкой Любовью Егоровой на чемпионате мира по лыжному спорту 1997 г. в норвежском городе Тронхейме. После случая с Б. Джонсоном мир, пожалуй, не знал столь громких дисквалификации, как в инциденте с JI. Егоровой. Она была дисквалифицирована и лишена золотой медали за употребление допинга

Летом 1998 г. Международный олимпийский комитет принял решение о проведении Международной конференции по допингу в спорте. 20 августа 1998 г. на совещании президента МОК, четырех вице-президентов и председателя Медицинской комиссии МОК были обозначены четыре темы, которые предстояло обсудить участникам конференции: «Защита атлетов», «Правовые и политические аспекты», «Этика и профилактическое образование», «Финансовые аспекты». Руководителями рабочих групп, которым предстояло осуществить подготовку к дебатам, стали вице-президенты МОК.

Co 2 по 4 февраля 1999 г. в Лозанне была проведена Всемирная конференция по допингу в спорте. В ней приняли участие более 600 человек - представителей международного олимпийского и спортивного движения, правительств, межправительственных и неправительственных организаций. Итогом работы конференции стала Лозаннская декларация о допинге в спорте, в которой нашли отражение наиболее принципиальные положения по шести разделам: «Образование, профилактика и права спортсменов», «Антидопинговый 
кодекс олимпийского движения», «Санкции», «Международное независимое антидопинговое агентство», «Ответственность МОК, МСФ и Спортивного арбитражного суда», «Сотрудничество олимпийского движения с общественными организациями».

В первом разделе говорится, что Олимпийская клятва должна распространяться на тренеров и других официальных лиц, включать уважение к принципам единства, этики и честной игры в спорте, а также о необходимости интенсифицировать образовательные и профилактические кампании, направленные главным образом на молодежь, спортсменов и их окружение; соблюдать полную открытость во всех видах деятельности по борьбе с допингом, за исключением тех случаев, когда конфиденциальность необходима для защиты основных прав спортсменов.

Впервые олимпийская клятва прозвучала в 1920 г.: «От имени всех спортсменов я обещаю. что мы будем участвовать в этих Играх, уважая и соблюдая правила, по которым они проводятся, без допинга и наркотиков, в истинно спортивном духе, во славу спорта и во имя чести-команд».

На конференции была также подчеркнута необходимость усилить сотрудничество в борьбе против допинга спортивных организаций со структурами государственной власти, так как именно государственные власти несут ответственность за определение санкций по отношению к торговцам запрещенными допинговыми средствами, а также в случаях, когда нарушение влечет наказание, выходящее за рамки спортивных санкций. Была достигнута договоренность и о том, что при содействии олимпийскому движению структуры государственной власти несут ответственность за приведение в соответствие национального и международного законодательств, которые относятся к допингу. Эти структуры должны также предпринимать совместные акции в сфере образования, научных исследованиях, социальных программах по защите спортсменов.

Одним из наиболее принципиальных решений конференции стало решение о создании независимого международного антидо- пингового агентства, в котором были бы представлены олимпийское движение, правительственные и соответствующие межправительственные организации. На реализацию этой цели олимпийское движение сразу выделило 25 млн долл. И 10 ноября 1999 г. в Лозанне прошло учредительное заседание Всемирного антидопингового агентства (ВАДА). Первым председателем Совета основателей ВАДА стал вице-президент МОК Ричард Паунд (Канада).

Борьбу с допингом МОК продолжил на своей 110-й сессии, которая прошла в Лозанне 1112 декабря 1999 г., приняв следующие решения:

1) клятва олимпийцев должна включать положение о спорте без допинга. Точный текст должен быть согласован с Комиссией атлетов. На Олимпийских играх в Сиднее в 2000 г. обещание не употреблять допинг впервые вошло в олимпийскую клятву;

2) чтобы получить допуск на Олимпийские игры, каждый атлет должен иметь «паспорт» с информацией, позволяющей проводить эффективный допинг-контроль и следить за состоянием его здоровья. Такую систему должно внедрить ВАДА;

3) как организация, ответственная за допинг-контроль во время Олимпийских игр, МОК будет проводить вне соревновательный допинг-контроль атлетов параллельно с процедурой их аккредитации;

4) в случае апелляции против санкций проба В должна пройти тест в лаборатории, отличной от той, где проверялась проба А ВАДА должно внедрить такую систему;

5) вид спорта, где не следуют Антидопинговому кодексу олимпийского движения, в частности не проводят внесоревновательных проверок в соответствии с правилами ВАДА, не может оставаться в программе Олимпийских игр. Если это относится к видам спорта, признанным МОК, то они потеряют такое признание.

Первым практическим шагом Всемирного антидопингового агентства стало проведение 2073 тестов на допинг перед Играми XXVII Олимпиады, в ходе которых было выявлено 23 нарушителя. Их имена не были 
обнародованы, но никого из них к участию в Играх не допустили. Во время проведения допинг-контроля на Играх в Сиднее МОК обнаружил 11 положительных проб. Все нарушители были наказаны. Шесть спортсменов лишились медалей, в том числе румынская гимнастка Андреа Радучан, болгарская спортсменка в тяжелой атлетике Изабелла Драглева и германский борец Александр Ляйпольд - золотых.

В канун чемпионата мира по легкой атлетике в Париже (23-31 августа 2003 г.) президент Федерации легкой атлетики Норвегии заявил, что основным вопросом современного спорта стал физиологический статус организма спортсменов с точки зрения равенства стартовых условий.

Зимняя Олимпиада в американском городе Солт-Лейк-Сити в 2002 г. обострила проблему допинга до предела. По данным Медицинской комиссии Международного олимпийского комитета, на этих Играх в период с 9 по 24 февраля 2002 г. у спортсменов было взято 623 образца биопроб. В результате Международная федерация лыжного спорта (ФИС) объявила о лишении медалей наших спортсменок Ларисы Лазутиной и Ольги Даниловой, кумира испанских болельщиков «трижды золотого» Йохана Мюллега, как и наши спортсменки подавшего жалобу в Международный спортивный арбитражный суд в Лозанне. Однако всем им в удовлетворении жалоб было отказано.

Скандальность Олимпиады-2002 окончательно обнажила отсутствие единообразных общепринятых ориентиров в подходах к оценке стартовых условий, в которых находятся спортсмены. Оказалось, что судейства недостаточно, для того чтобы выяснить первенствующего в спортивном состязании. Создание одинаковых стартовых условий организационными средствами также не гарантирует, что спортсмены равны в возможностях.

Этой внешней стороне устройства соревнования и оценки спортивных достижений противостоит другая их сторона - внутренняя, которая представлена физиологией организма спортсмена. До поры оставаясь незаметной или по крайней мере будучи в поле зрения как не имеющая определяющего значения, физио- логия организма спортсмена в последнее время стала проблемой. Без сомнения, потенциал высших спортивных достижений, сосредоточенный в физиологических возможностях организма спортсмена, подвержен управлению извне. Воздействия, прежде всего фармакологического характера, способны значительно повлиять на эффективность одних и тех же усилий. Тем самым при одинаковых физиологических параметрах соответствующее воздействие на организм может обусловить прогнозируемый эффект различной управляемой величины. Для физиологических параметров конкретного спортсмена можно подобрать максимально эффективное воздействие. Но и для соответствующего воздействия можно найти спортсмена с максимально подходящей реакцией организма. Так или иначе спортивное достижение становится выражением эффективности внешнего воздействия на организм спортсмена.

Использование допинга несет значительную опасность для здоровья спортсмена. Действие допинговых веществ на организм зависит от пола, возраста, здоровья, особенностей нервной системы и обмена веществ, условий среды и других факторов. Искусственно стимулируя организм, допинговые вещества оказывают возбуждающее действие на центральную нервную систему, снимают охранительное торможение, создают ложное чувство повышения возможностей и отсутствия утомления, нарушают нормальную регуляцию функций, обусловливают нерациональную, неэкономную их деятельность при физических напряжениях, и без того связанных с предельной мобилизацией функций. Они способствуют исчерпанию ресурсов организма от перенапряжения, способствуя его возникновению, что (особенно на фоне некоторых отклонений в состоянии здоровья, недостаточной тренированности или переутомления, возрастных особенностей, неблагоприятных условий среды и др.) может вызвать невротические расстройства, острую сердечную недостаточность, инфаркт миокарда и привести даже к смертельному исходу.

После относительно кратковременного возбуждения функций наступают их угнетение и 
падение работоспособности. Под влиянием допинга могут наблюдаться нарушения спортивной техники и ориентировки, снижение логического мышления, немотивированные изменения поведения и выраженная агрессивность.

Допинг-препараты известны давно. Уже в XIX в. атлеты употребляли стрихнин, в малых дозах вызывавший кратковременный стимулирующий эффект. Или хотя бы такой старинный допинг, как кофе* «Выпейте 18 чашек за короткое время - получите запретную дозу кофеина». Упоминание о кофе не случайно. В 2001 г. на Чемпионате мира по легкой атлетике в канадском городе Эдмонтоне у нашей метательницы диска Натальи Садовой, завоевавшей золотую медаль в допинг-пробе был обнаружен излишек кофеина. Тяжба между отечественной федерацией и ИААФ тянулась больше года, и весной 2003 г. было решено лишить Садову титула и медали. То, что причиной могла быть лишняя чашка кофе, во внимание не принималось. Есть нарушение результат спортсменки аннулируется.

Отношение к стимуляторам изменилось за последние десятилетия. Существующий спортивный правопорядок не допускает использования спортсменами веществ, методов, способствующих повышению их работоспособности и запрещенных для использования законодательством отдельного государства и (или) решениями Международного олимпийского комитета, Всемирного антидопингового агентства, иных международных спортивных организаций. В ряде стран действуют законы об уголовной ответственности за применение и распространение допинга.

На международном уровне государства члены Совета Европы, иные государства - участники Европейской культурной конвенции, а также ряд других 16 ноября 1989 г. в Страсбурге подписали Конвенциию против применения допинга ETS № 135(далее также - Конвенция № 135). Подписавшие ее страны сделали это:

считая, что задачей Совета Европы является обеспечение более тесного союза между его членами с целью сохранения и развития идеалов и принципов, являющихся их общим достоянием, а также содействие их социально-экономическому прогрессу; сознавая, что спорт должен играть важную роль в охране здоровья, моральном и физическом воспитании, в деле углубления международного взаимопонимания.

Первым участником соревнований, попавшимся на допинге в Афинах, стал кенийский боксер Дэвид Муньяса. 10 августа, за три дня до открытия Игр, пресс-секретарь МОК сообщил, что в организме спортсмена обнаружен запрещенный препарат катин, обладающий свойствами амфетаминов. МОК отстранил боксера от участия в Играх и призвал Международную любительскую федерацию бокса применить к нему дисциплинарные санкции. Спортсмен подал протест в Спортивный арбитражный суд в Лозанне, но суд апелляцию отклонил. Федерация бокса Кении дисквалифицировала Дэвида Муньясу на два года.

Утром 12 августа группа Всемирного антидопингового агентства (WADA) неожиданно устроила проверку в Рефимно - резиденции легкоатлетической сборной США. После прохождения теста глава делегации США Джим Шер сочтя, что американцев незаслуженно подозревают и проверяют больше других, потребовал от МОК провести допинг-контроль греческих спринтеров. Во второй половине дня медкомиссия прибыла в Олимпийскую деревню в Афинах для проверки греческих спортсменов, но не обнаружила там спринтеров Костаса Кентериса и Катерину Тану. Первый должен был участвовать в церемонии зажжения олимпийского огня на стадионе в Афинах, и его исчезновение показалось подозрительным. Комиссия МОК дала греческой сборной два часа на поиск атлетов. Вечером команда представила МОК документ. в котором говорилось, что пропавшие «отправились домой за вещами». Ночью во время заседания дисциплинарной комиссии МОК. посвященного проблеме Кентериса и Тану. стало известно, что спринтеры, приглашенные на заседание, госпитализированы после мотоциклетной аварии (по данным греческой стороны они госпитализированы после мотоциклетной аварии по дороге на допинг-контроль) Греки настаивали, что атлеты травмированы, находятся в больнице и предстать перед дисциплинарной комиссией не могут. 
Между тем над Кентерисом и Тану нависла угроза дисквалификации сроком до двух лет, поскольку отказ от сдачи тестов приравнивается к употреблению допинга. После того как общественности стало известно о происшествии, 14 августа легкоатлетическая сборная Швеции пригрозила бойкотировать игры, если Кентериса и Тану допустят к турниру. Официальный представитель шведской команды Свен Сторакерс заявил: «Мы обсудили возможность отъезда, нос нетерпением подождем решения МОК». В тот же день руководство греческой сборной пятью голосами против одного, приняло решение исключить обоих спортсменов из состава команды. 20 августа на квартире тренера Кентериса и ТануХристоса Цекоса полиция в ходе обыска обнаружила 641 упаковку препаратов, содержащих запрещенные пищевые добавки и эфедрин. Греческие спринтеры так и не приняли участия в 0лимпиаде-2004.26 августа Международная легкоатлетическая ассоциация приняла решение начать расследование е связи с их неявкой на допинг-контроль.

14 августа штангистка из Мьянмы Нан Айс Кии заняла четвертое место в соревнованиях в весовой категории до 48 кг. 16 августа МОК объявил, что ее допинг-тест оказался положительным. Результат спортсменки был аннулирован, она лишилась олимпийской аккредитации. Нан АйсКин заявила. что никогда не принимала запрещенных препаратов, и предположила, что, возможно, непроверенные лекарства ей давал ее врач. Заступиться за штангистку было некому, незадолго до Игр МИД Греции по просьбе ЕС и США. наложивших санкции на военный режим в Мьянме. отказал в визе министру спорта этой страны бригадному генералу Эй Мьинту. После дисквалификации Нан Айс Кин в команде Мьянмы осталась только одна спортсменка - лучница Тин Кхайнг.

16 августа греческий тяжелоатлет Леонидас Сампанис завоевал бронзовую медаль в весовой категории до 62 кг. набрав 312,5 кг (рывок - 145. толчок - 167,5). 18 августа греческая почтовая организация ЭЛТА начала рекламную кампанию новой серии марок с изображениями призеров Олимпиады, сре- ди которых был и Сампанис. Но уже 20 августа Олимпийский комитет Греции, а затем Международная федерация тяжелой атлетики сообщили, что допинг-тест призера дал положительный результат.

В сентябре 2001 г. на Играх доброй воли в австралийском городе Брисбейне лидеры мировой художественной гимнастики Алина Кабаева и Ирина Чащина были обвинены в употреблении фуросемида. Это вещество само по себе не является допингом, но, по мнению некоторых специалистов, якобы способно затушевывать действие запрещенных препаратов. Правда, те же специалисты считают, что применение допинга в художественной гимнастике совершенно бессмысленно с любой точки зрения.

Так или иначе Международная федерация гимнастики дисквалифицировала Кабаеву и Чащину на один год. В результате рассмотрения апелляции российской стороны Международным спортивным арбитражным судом в Лозанне это решение было признано обоснованным. После того скандала А. Кабаева и И. Чащина с блеском выиграли несколько крупнейших международных соревнований, доказав, что ни в каком допинге не нуждаются.

«Допинговые скандалы» все чаще омрачают радость побед в различных видах спорта. «Чемпионом» здесь стали XIX зимние Олимпийские игры в Солт-Лейк-Сити. Инцидент Олимпиады в Солт-Лейк-Сити связан с именем российского биатлониста П. Ростовцева. В нарушение всех принятых норм за час до начала спортивных соревнований организаторы Олимпийских игр обязали россиянина пройти допинг- контроль, который в итоге не выявил никаких нарушений, но психологически подавил биатлониста. Это явилось одной из причин поражения российского спортсмена явного фаворита соревнований

Специфика деятельности спортсменов, широкая известность многих из них, мигрирующий характер их спортивного быта - все это является привлекательными, к сожалению, доступным нечистым на руки и дела людям, стремящимся спортивную тему использовать как сферу собственно- 
го моральною прежде всего материального благополучия.

Наиболее опасная сфера деформации - это наркотизм. Среди наркоманов нередко встречаются те, кто ранее занимался спортом, притом весьма успешно: почти $18 \%$ из них имели спортивные разряды. В связи с этим А.А. Габиани пишет: «Причины, толкающие бывших спортсменов в дурманный омут, как правило, две: неудачи, внезапное прекращение роста спортивных достижений и то, что обычно называют “не выдержал испытания славой”, когда успехи кружат голову и человек начинает считать себя вправе безнаказанно совершать любые поступки. Но наказание за наркотик неотвратимо, а слабый духом (а это именно так, ведь сколько мы знаем спортсменов, которые не дрогнули перед самыми жесткими ударами судьбы, не утратили скромности под “бременем” всемирной известности, не стали робами страшного недуга.

Наконец, не следует сбрасывать со счетов и то обстоятельство, что, к сожалению, порочная практика применения допинговых средств в погоне за высокими спортивными результатами не изжита еще окончательно. Отсюда тоже протягивается один из мостиков, приближающих спортсмена к зелью» ${ }^{1}$.

По словам спортсменов, довольно часто они и не знали, что употребляют допинг, так как тренер или врач команды скрывает их истинное предназначение, предлагая их под видом витаминов. Тренер, врач команды, ее руководитель должны нести ответственность по ст. 230 действующего уголовного законодательства в случае склонения спортсмена к употреблению допинга. Очевидно, что основные причины употребления допинга лежат в структуре самого спорта, в стремлении спортсмена, тренера любой ценой достичь рекордного результата.

Идентично распространению наркотических средств, такие деяния следует систематизировать в Законе, условно, обозначив: «Распространение допинговых препаратов различного типа». Не секрет, что стероиды и

${ }^{1}$ См.: Габиани A.A. Но краю пропасти: наркомания и наркоманы. М.: Мысль, 1990. С. 88, 89. другие виды допингов становятся предметом все более расширяющегося нелегального бизнеса.

С медико-правовых позиций требуют толкования такие термины, как: стимуляторы, допинги, психоактивные вещества и средства, новый термин - «токсикоманическое вещество и средство». Все приведенные термины и их толкования требуют систематизации и кратких формулировок их определений.

В 1971 г. после принятия Конвенции о психотропных веществах традиционно применяемый термин «психотропные вещества» приобрел уже юридический оттенок. Упомянутая Конвенция определила, что в список психотропных веществ могут включаться только те, которые вызывают патологическое привыкание, оказывают стимулирующее или депрессивное воздействие на центральную нервную систему (ЦНС), вызывают галлюцинации или нарушения моторной функции либо мышления, либо поведения, либо восприятия, либо настроения, и если такое воздействие может представить собой проблему для здоровья населения и социальную проблему. Отсюда - в современном понимании с позиции международного права термин «психотропные вещества» означает вещества, которые включены в соответствующие Списки Конвенции о психотропных веществах 1971 г. С позиции национального права психотропными веществами являются те вещества, которые включены в Перечень наркотических средств, психотропных веществ и их прекурсоров, подлежащих контролю в Российской Федерации, утвержденный Постановлением Правительства РФ от 30.06.98. № 681. Национальные Списки РФ не повторяют Список психотропных веществ Конвенции 1971 г., что не является нарушением международного обязательства Российской Федерации, так как ст. 23 Конвенции 1971 г. предоставляет право Сторонам Конвенции иметь более строгие меры контроля. Соответственно в Списках РФ многие психотропные вещества включены в Списки наркотических средств, например: ЛСД, амфетамины, тетрогидроканнабинолы и т.д. Кроме того, в национальные Списки психотропных веществ включены и другие вещества, еще не включенные в 
Списки Конвенции 1971 г., так как они представляют определенную опасность на региональном уровне. Такое положение также предусматривается международным правом.

С медицинских позиций психоактивность может выразиться в особом воздействии на ЦНС, в способности стимулировать, вызывать эйфорию, возбуждать, вызывать галлюцинации или, наоборот, оказывать снотворный эффект, успокаивать и т.п. Такое воздействие характерно для наркотических, психотропных и ряда других веществ, в настоящее время не отнесенных к вышеуказанным двум группам. Таким образом, психоактивные вещества - собирательное понятие, включающее большую группу специфически действующих на ЦНС средств. Соответственно, эту большую группу можно разделить на психоактивные средства, находящиеся и не находящиеся под международным и национальным контролем.

Психоактивные вещества, находящиеся под международным и национальным контролем:

- наркотические средства:

а) лекарственные средства;

б) вещества, не отнесенные к лекарственным средствам;

в) вещества, запрещенные для применения человеком;

- психотропные вещества и средства:

а) лекарственные средства;

б) вещества, не отнесенные к лекарственным средствам;

в) вещества, запрещенные для применения человеком;

- сильнодействующие вещества:

а) лекарственные средства;

б) вещества, не отнесенные к лекарственным средствам.

Психоактивные вещества и средства, не находящиеся под международным и национальным контролем.

Вещцества и средства, не отнесенные к наркотическим и психотропным, но оказывающие вымеописанное действие на ЦНС человека:

a) лекарственные средства, например, кофеин; б) вещества и средства, не отнесенные к лекарственным средствам, например, кофе, чай, кока-кола, элеутерококк и многие другие. В эту же группу входят все вещества, вызывающие токсикоманию (органические растворители и др.).

Термин «психоактивное средство» чаще всего целесообразно применять к тем средствам, которые не отнесены к наркотическим и психотропным и соответственно не находятся под международным и национальным контролем, так как к последним необходимо применять термины, под которыми они значатся как в международном, так и в национальном праве.

Изучение всей номенклатуры лекарственных средств, отнесенных с фармакологической позиции стимуляторам показывает, что часть средств и веществ, отнесенных к наркотическим средствам, контролируется в рамках Единой конвенции о наркотических средствах (1961 г.), другая - находится в Списках Конвенции о психотропных веществах (1971г.) и, соответственно, в Перечне наркотических средств, психотропных веществ и их прекурсоров, подлежащих контролю в Российской Федерации, утвержденном Постановлением Правительства РФ от 30.06.98. № 681. Остается еще третья группа стимулирующих и лекарственных средств и веществ, которые в настоящее время еще не отнесены ни к одной из приведенных двух групп и потому не находятся под контролем. Такое деление важно, так как очевидно, что нарушение порядка производства, использования, хранения стимуляторов, отнесенных к разным группам, влечет за собой соответствующие юридические последствия в рамках международного и национального права.

Таким образом, с правовой позиции сегодня возникла необходимость, говоря о стимуляторах, всегда указывать, к какой группе они отнесены. Специалистами было отмечено, что ряд стимуляторов сделались предметом злоупотребления спортсменов. Такие стимуляторы были запрещены для применения в спорте, и постепенно группа этих препаратов стала расширяться. Однако предметом злоупотребления начали становиться не только стиму- 
ляторы, но и другие препараты, в том числе оказывающие успокаивающее действие, также ряд гармональных препаратов. В последнее десятилетие такого типа препараты начали называть допингом, однако не всегда этот термин применяется правильно. В современном понимании допингом следует называть те стимуляторы и психоактивные препараты, а также наркотические и психотропные, эндокринные и другие средства, которые искусственно создают благоприятное для достижения спортивных целей физическое состояние, в связи с чем уполномоченным на то органом в установленном порядке признаны допингами и включены в соответствующие юридические документы.

Таким образом, так же как и наркотические, и психотропные вещества, понятие «допинг» более правовое, чем фармакологическое.

Поднятые ранее проблемы законодательно были закреплены в Конвенции против применения допинга (CED № 135), Страсбург, 16. 10. 1989 г. Согласно отдельным выдержкам из текста данного документа следует:

«Государства - члены Совета Европы, другие государства - участники Европейской культурной конвенции, а также государева, подписавшие настоящую Конвенцию,

будучи озабоченными все более широким употреблением спортсменами во всех видах спорта средств и методов допинга, равно как и последствиями такого употребления для здоровья людей и для будущего спорта;

принимая к сведению, что эта проблема ставит под угрозу этические принципы и образовательные ценности, провозглашенные Олимпийской хартией, Международной хартией спорта и физического воспитания ЮНЕ$\mathrm{CKO}$, а также Резолюцией (76) 41 комитета министров Совета Европы, известной под названием Европейская хартия «Спорт для всех»:

учитывая правила, меры и декларации, принятые международными спортивными организациями в области борьбы против допинга;

осознавая, что государственные органы и добровольные спортивные общества несут дополнительную ответственность в борьбе против допинга в спорте, в частности, в деле обеспечения гарантий должного проведения спортивных мероприятий на основе принципа честной игры, а также в деле укрепления здоровья тех, кто принимает в них участие;

признавая, что эти органы и общества должны сотрудничать на всех соответствующих уровнях;

напоминая резолюции о допинге, принятые Конференцией европейских министров, ответственных за спорт, и в частности Резолюцию № 1, принятую в 1989 году на 6-й конференции в Рейкьявике;

напоминая, что Комитет министров Совета Европы уже принял Резолюцию (67) 12 о допинге спортсменов, Рекомендации №R(79) 8 относительно допинга в спорте, Рекомендации № R(84) 19 относительно Европейской хартии против допинга» спорте и Рекомендацию № $\mathrm{R}(88) 12$ относительно введения антидопингового контроля вне соревнований и без предварительного уведомления;

напоминая Рекомендацию № 5 о допинге, принятую 2-й Международной конференцией министров и руководящих работников, ответственных за физическое воспитание и спорт, проведенной ЮНЕСКО в Москве (1988 г.);

преисполненные, вместе с тем, решимостью продолжать укреплять их сотрудничество, направленное на снижение и в конечном счете искоренение допинга в спорте, с учетом этических; ценностей и практических мер, содержащихся в этих документах, договорились о нижеследующем:

В целях снижения и в конечном счете искоренения допинга в спорте Стороны обязуются принять в рамках своих соответствующих конституционных положений меры, необходимые для осуществления настоящей Конвенции.

1. Для целей настоящей Конвенции: «допинг в спорте» означает введение спортсменам или применение ими различных видов фармакологических допингов препаратов или методов допинга;

2. «виды фармакологических допинговых препаратов или методы допинга» с учетом нижеследующего пункта 2 означают тип допинговых препаратов и методы допинга, перечисленные в списках».

Применение норм Конвенции послужило лишению семи титулов «Тур де Франс» и дис- 
квалификации пожизненно известного велогонщика Лэнса Армстронга.

Окружной суд Техаса отказал в удовлетворении иска Лэнса Армстронга против Антидопингового агентства США (USADA). Велогонщик пытался признать незаконными действия USADA, которое ведёт антидопинговое разбирательство в отношении спортсмена. Спортсмен не обязан обжаловать данное решение. Свой отказ от обжалования Армстронг объяснил тем, что его тяготят регулярные разбирательства и он устал бороться с правосудием.

«Я знаю, кто на самом деле выиграл все эти семь «Туров», мои партнеры по команде тоже это прекрасно понимают. Да и каждый, кто соперничал со мной, знает о том, кто настоящий победитель», - заявил Армстронг на своем официальном сайте.

Вот как прокомментировал эти слова президент Всемирного антидопингового агентства (WADA) Джон Фэйхи, который отметил, что $\boldsymbol{y}$ Армстронга было право обратиться в арбитражный суд, но он решил не делать этого. Несложно догадаться, что его решение не выставлять доказательства на всеобщее обозрение свидетельствует о действительном наличии запрещенных веществ в пробах. По всем правилам жесткие санкции теперь могут быть применены к Армстронгу.

Исполнительный директор Американского антидопингового агентства (USADA) Трэвис Тигарт выразил надежду на то, что пример Армстронга поможет другим спортсменам избежать ошибок: «Это грустный день для всех нас, кто любит спорт и его героев. Мы видим душераздирающий пример того, как подход к спорту, подразумевающий добычу победы любой ценой, может взять верх над честным, безопасным и добросовестным соревнованием атлетов. Но для чистых спортсменов случай Армстронга дает надежду на то, что будущие поколения будут соревноваться на высшем уровне без применения допинга».

Напомним, что ранее сотрудники USADA провели анализ образцов крови Армстронга, взятых в 2009-2010 гг., и полученные данные свидетельствовали о «манипуляциях с кровью», в том числе об использовании стимулирующих веществ, маскирующих пре- паратов и о переливаниях крови. На период рассмотрения дела велогонщик был отстранен от выступления в соревнованиях.

Кроме того, по данному делу USADA выдвинуло обвинения против еще пяти человек. Это менеджер четырех велогоночных команд Армстронга Йохан Брюнель (Johan Bruyneel), бывшие врачи команды Луис Гарсия дель Мораль (Luis Garcia Del Moral) и Педро Селайя(PedroCelaya), бывший тренер Хосе Марти (lose Marti) и врач-консультант Мишель Феррари (MicheleFerrari). Конкретно они обвиняются в хранении, перевозке, назначении и использовании запрещенных стимулирующих препаратов.

Армстронг был уличен в использовании запрещенных препаратов по итогам расследования Американского антидопингового агентства (USADA), Международный союз велосипедистов (UCI) пожизненно дисквалифицировал уже завершившего к тому времени карьеру спортсмена, аннулировав результаты всех его выступлений, начиная с 1998 г., включая семь побед на «Тур де Франс». Американской телеведущей Опре Уинфри Армстронг публично признался в употреблении запрещенных препаратов. В книге, которая была опубликована до допинг-скандала, Лэнс отрицал факты употребления препаратов во время своих побед на «Тур де Франс».

Консультант республиканской партии Роб Стацман и шеф-повар Джонатан Уилер из Сакраменто подали судебный иск на Лэнса Армстронга из-за его мемуаров, в которых американец отрицает употребление допинга.

«Мы бы не приобрели эти книги, если бы знали истинные факты относительно успехов Армстронга и информацию о его участии в допинговом скандале», - сказано в заявлении Стацмана и Уилера, которое поступило в федеральный суд Калифорнии.

В иске фигурируют книги «Не только о велоспорте: мое возвращение к жизни» и «Каждая секунда на счету». «Стацман купил книгу в Калифорнии и прочел ее от корки до корки, - сказано в исковом заявлении. - Хотя Стацман не покупает и не читает слишком много книг, он нашел книгу Армстронга невероятно убедительной и порекомендовал ее некоторым своим друзьям». 
Второй истец Уилер, будучи заядлым велосипедистом, купил книгу Армстронга и был «так впечатлен», что купил и последующее произведение экс-велогонщика.

Промоутерская компания SCA Promotions также подала на Армстронга в суд, требуя вернуть 12 млн долл., которые были выплачены спортсмену за победы на «Тур де Франс».

В иске говорится, что за победы в гонке с 2002 по 2004 г. компания выплатила Армстронгу 9,5 млн долл. призовых, а также 2,5 млн на покрытие расходов. В качестве ответчикөв пө иску выступают сам велогонщик, атакже его агент Билл Стэплтон.

«Для мистера Армстронга настало время столкнуться с последствиями своих действий. Он признался, что употреблял допинг, запугивал людей, лгал», - говорится в иске.

Ранее адвокат Армстронга Тим Херман заявил, что его клиент не станет возвращать эти деньги.

Два новых судебных иска были выдвинуты уже в 2013 г. против экс-велогонщика. В американский суд на Армстронга подали страховая компания из Небраски и спортивная корпорация из Сан-Франциско, которые утверждают, что велогонщик совершил мошенничество, скрыв от них факт использования допинга, когда он участвовал в велогонке «Тур де Франс» в 1999,2000 и 2001 гг. Компании требуют от Армстронга возместить им 3 млн долларов, полученных от них спортсменом. Юридическая ответственность, как правило, «подразделяется по отраслевому признаку на уголовную, гражданскую, административную, дисциплинарную, материальную, процессуальную и конституционную, при этом выделяются следующие признаки юридической ответственности:

она предусмотрена действующим законодательством (уголовным, гражданским, административным и др.);

наступает за правонарушения при наличии полного его состава;

опирается на государственное принуждение;

выражается в определенных неблагоприятных для правонарушителя последствиях, лишении его известных социальных благ (свободы, имущества, прав и т.д.); возлагается и реализуется в установленной законом процессуальной форме, нарушение процедурных норм также влечет за собой ответственность;

правонарушитель наказывается от имени государства, в отличие, например, от моральной ответственности, которая исходит от негосударственных структур;

осуществляется уполномоченными на то компетентными органами и должностными лицами в строго определенном порядке и в пределах своих прерогатив.

Исходя из указанных выше признаков юридической ответственности, можно сделать вывод, что спортивная ответственность не относится к юридической ответственности, поскольку она не опирается на государственное принуждение и правонарушитель спортивных правил не наказывается от имени государства.

«Спортивная ответственность и юридическая ответственность имеют много общего, виды юридической ответственности, как уголовная, административная, гражданско-правовая, дисциплинарная и т.п., относятся к традиционным видам, они хорошо исследованы и именно на результатах их исследования ученые формулировали характерные признаки юридической ответственности. В то время как спортивная ответственность, естественно, не изучалась как самостоятельное явление до появления спортивного права. Ее нельзя отнести к традиционным видам юридической ответственности, но на свое существование, как нетрадиционный (особый) вид юридической ответственности, спортивная ответственность имеет полное право.

Правовым основанием для возникновения спортивной ответственности как явления следует рассматривать Федеральный закон от 4 декабря 2007 г. № 329-ФЭ «О физической культуре и спорте в Российской Федерации», ст. 16 которого устанавливает, что общероссийские спортивные федерации могут утверждать нормы, устанавливающие права и обязанности, в том числе спортивные санкции, для признающих такие нормы субъектов физической культуры и спорта.

На основе признаков, сформулированных для юридической ответственности, можно 
выделить следующие признаки спортивной ответственности:

она предусмотрена регламентирующими документами общероссийских спортивных федераций и носит делегированный характер, т.е. законодатель закрепляет в федеральном законе возможность установления и применения спортивных санкций общероссийскими спортивными федерациями;

наступает за совершение правонарушений в сфере физической культуры и спорта, установленных правилами вида спорта и регламентирующими документами общероссийских спортивных федераций;

опирается не на государственное принуждение, а на признание субъектами физической культуры и спорта возможности общероссийских спортивных федераций применять к ним спортивные санкции т.е. спортивная ответственность зависит от факта добровольного признания - пока субъект физической культуры и спорта является участником спортивных соревнований и признает нормы общероссийской спортивной федерации, его можно привлечь к спортивной ответственности;

выражается в определенных неблагоприятных для правонарушителя последствиях, которые также устанавливаются общероссийскими спортивными федерациями, при этом такие неблагоприятные последствия, как правило, связаны с участием в спортивных соревнованиях;

возлагается и реализуется в процессуальной форме, установленной регламентирующими документами общероссийской спортивной федерации;

правонарушитель наказывается не от имени государства, а от имени общероссийской спортивной федерации, установившей норму, которая была нарушена;

осуществляется уполномоченными юрисдикционными органами общероссийской спортивной федерации в пределах полномочий, определенных самими общероссийскими спортивными федерациями.

Сформулировав признаки спортивной ответственности, можно дать следующее определение: спортивная ответственность - это применение мер принуждения со стороны об- щероссийской спортивной федерации к лицу, признающему нормы, утвержденные такой общероссийской спортивной федерацией, за совершение спортивных правонарушений.

Презумпция невиновности - означает, что лицо считается невиновным, пока его вина не будет доказана в порядке, установленном спортивными регламентами. Исключением из этого принципа являются дела, связанные с нарушением антидопинговых правил, где сам факт выявления в организме спортсмена запрещенного вещества является доказательством его вины, и для не привлечения к ответственности спортсмен должен доказать свою невиновность («Если спортсмен докажет отсутствие своей вины или халатности в каждом конкретном случае, то назначенный срок дисквалификации должен быть отменен. Если запрещенная субстанция, или ее маркеры, или метаболиты обнаружены в пробе спортсмена в нарушение статьи 2.1 (наличие запрещенной субстанции), то спортсмен должен также объяснить, как запрещенная субстанция попала в его организм, чтобы дисквалификация была отменена» - п. 10.5.1 Всемирного антидопингового кодекса ВАДА);

Принцип честной игры («fairplay») - предполагает, что спортивное соревнование должно проводиться по определенным правилам, а участники такого соревнования должны соблюдать эти правила и уважительно относиться друг к другу, нарушение же установленных правил должно пресекаться и наказываться.

Как уже было отмечено, спортивная ответственность носит делегированный характер и основана на возможности установления общероссийскими спортивными федерациями спортивных санкций за нарушение утверждаемых ими норм. Такая возможность закреплена п. 5 ч. 1 ст. 16 Федерального закона от 4 декабря 2007 г. № 329-Ф3 «О физической культуре и спорте в Российской Федерации».

В отличие от той же уголовной либо административной ответственности, где есть кодифицированный акт, фиксирующий запрещенные деяния и наказания, применяемые за их совершение, спортивная ответственность не располагает своим единым кодифицированным актом. Кроме того, перечень 
запрещенных деяний и виды санкций могут различаться в зависимости от вида спорта.

Среди документов, регламентирующих спортивную ответственность, можно выделить следующие:

правила видов спорта (например, правила игры в футбол, правила баскетбола и т.п.);

спортивные регламенты, утверждаемые организаторами соревнований (например, Дисциплинарный регламент РФС, Дисциплинарный регламент КХЛ и т.п.);

документы международных антидопинговых организаций (Всемирный антидопинговый кодекс ВАДА) и общероссийские антидопинговые правила.

Спортивное правонарушение можно определить как противоправное виновное, наказуемое деяние в форме действия или бездействия, запрещенное правилами вида спорта или спортивными регламентами.

Спортивные правонарушения можно группировать по нескольким основаниям:

1. По документам, устанавливающим запрет на совершение спортивного правонарушения, можно выделить следующие виды спортивных правонарушений: нарушения правил вида спорта; нарушения спортивных регламентов; нарушения антидопинговых правил.

2. По объекту правонарушения спортивные правонарушения можно разделить на:

нарушения против порядка управления (использование подложных документов при регистрации для участия в соревнованиях, нарушение антидопинговых правил.

Законодательство о физической культуре и спорте в Российской Федерации упоминает только одну спортивную санкцию - спортивную дисквалификацию спортсмена, под которой понимается «отстранение спортсмена от участия в спортивных соревнованиях, которое осуществляется международной спортивной федерацией по соответствующему виду спорта или общероссийской спортивной федерацией по соответствующему виду спорта за нарушение правил вида спорта или положений (регламентов) спортивных соревнований, или антидопинговых правил или норм, утверждённых общероссийскими спортивными федерациями» (п. 14 ст. 2 Федерального закона от 4 дека- бря 2007 г. № 329-Ф3 «О физической культуре и спорте в Российской Федерации).

Олимпийский комитет России:

пропагандирует в Российской Федерации принципы олимпийского движения, способствует развитию спорта высших достижений и массового спорта;

представляет в соответствии с Олимпийской хартией Российскую Федерацию на Олимпийских играх;

утверждает состав олимпийской делегации Российской Федерации и направляет ее для участия в Олимпийских играх;

обеспечивает спортивную экипировку, проезд, проживание и страхование членов олимпийской делегации Российской Федерации на Олимпийских играх;

утверждает официальную спортивную форму и спортивную экипировку членов олимпийской делегации Российской Федерации;

участвует в разработке и осуществлении мер, направленных на обеспечение необходимого уровня подготовки российских спортсменов для участия в Олимпийских играх;

определяет город Российской Федерации, который вправе подать в Международный олимпийский комитет заявку на про ведение Олимпийских игр;

содействует предотвращению допинга в спорте и борьбе с ним, а также противодействию проявлениям любых форм дискриминации и насилия в спорте;

осуществляет иные права в соответствии с Олимпийской хартией и своим уставом, в том числе право на участие в обеспечении подготовки российских спортсменов для участия в Олимпийских играх.

Установление особенностей оборота лекарственных средств, наркотических препаратов и алкогольной продукции.

Исходя из вышеизложенного, для Игр Олимпиады в Сочи 2014 г. были разработаны меры безопасности:

в целях употребления спортсменом без должного подтверждения медицинской необходимости, одного или нескольких запрещенных веществ или средств;

фальсификации, порче или уничтожению любых проб, образцов или анализов, полу- 
ченных при проведении контрольных мероприятий.

Нет оснований заимствовать правовые предписания Спортивного кодекса Франции или французскую модель кодификации законодательства о спорте в неизменном виде, но учесть положительный французский опыт при совершенствовании и кодификации отечественного законодательства о спорте вполне целесообразно.

Так, когда начаты процессуальные действия, Французское агентство по борьбе с употреблением допинга может осуществлять права гражданского истца. Однако агентство не может по отношению к одному и тому же лицу и, основываясь на одних и тех же фактах, одновременно осуществлять дисциплинарные полномочия, которыми оно обладает в силу Спортивного кодекса, и права гражданского истца (ст. L. 232-30).

Правонарушения в области борьбы с допингом для животных (ст. L. 241-5).

1. Нарушения запрета на назначение и применение к животным во время спортивных соревнований или мероприятий или с целью участия в них веществ или средств, которые могут искусственно изменять их способности или которые скрывают применение веществ или средств, имеющих это свойство, наказывается пятью годами тюремного заключения и штрафом в размере 75 тыс. евро.

2. Незаконное изъятие животного или препятствование любым способом мерам антидопингового контроля наказываетсязаклюй и штрафом в размере 7500 евро.
3. Покушение на совершение правонарушении, предусмотренных в ст. L. 241 -5, что влечет за собой те же наказания, что и совершение правонарушений.

4. Юридические лица, в уголовном порядке признанные ответственными за правонарушения, предусмотренные в ст. L. 241-5, подвергаются наказаниям, предусмотренным в ст. L. 232-28.

В своей практике Спортивный суд в Лозанне сталкивается со множеством проблем современного спорта, таких как: допинг и иные медицинские средства улучшения спортивных результатов (например, смена пола спортсменом); ошибки судей-рефери на соревнованиях; влияние СМИ на спортсменов зависимость от спонсоров; политическая конкуренция государств, проявляющаяся и в агрессии на спортивных соревнованиях; предвзятость и лояльность судейства (например, по отношению к спортсменам, представляющим страну - организатора соревнований); использование правовых инструментов (принятие в гражданство перспективного спортсмена - натурализация); тотализаторы; компьютерные и иные преступления с использованием современной аппаратуры и техники (например, для сбоя приборов, фиксирующих результат, ослепление спортсменов лазерными указками и т.п.).

В связи с этим целесообразно обратиться к опыту САС при возникновении конфликтных ситуации во время проведения всех международных спортивных соревнований, например универсиад. Как известно, Универсиада - международное соревнование студентов (своего рода аналог Олимпиады), проводимое с 1959 г.

\section{Библиография:}

1. Габиани А.А. Но краю пропасти: наркомания и наркоманы. М.: Мысль, 1990. С. 88, 89

2. Л.И. Фусу. Эпидемиологические детерминанты развития депрессивного синдрома у лиц, злоупотребляющих наркотическими веществами // Психология и Психотехника. - 2013. - № 6. - C. 104-107. DOI: 10.7256/2070-8955.2013.6.6985.

3. Лопатина В.В.. Проблемы наркотрафика и легализация наркотиков в Латинской Америке // Международные отношения. - 2014. - № 1. - C. 104-107. DOI: 10.7256/2305-560X.2014.1.10242.

4. Чирков Д.К., Евланова О.А., Коимшиди Г.Ф.. Региональные особенности и различия преступлений в сфере незаконного оборота наркотиков // Национальная безопасность / nota bene. 2013. - № 6. - C. 104-107. DOI: 10.7256/2073-8560.2013.6.9679. 
5. Я.С. Карпов. Аналоги и производные наркотических средств и психотропных веществ: актуальные проблемы определения, квалификации и контроля // Национальная безопасность / nota bene. - 2012. - № 5. - C. 104-107.

6. Е. А. Попов. Особенности деятельности служб, связанных с противодействием наркотической зависимости населения // Право и политика. - 2012. - № 10. - С. 104-107.

7. Е. А. Попов. Криминологические и социальные особенности механизма противодействия наркотизации // Право и политика. - 2012. - № 6. - С. 104-107.

8. Т. В. Керимова. Риск состояния зависимости // Политика и Общество. - 2012. - № 2. - С. $104-$ 107.

9. Г. М. Горничар. Пробелы в статье 230 УК РФ: склонение к потреблению наркотических средств или психотропных веществ // Право и политика. - 2011. - № 9. - С. 104-107.

10. В.В. Лошкарев. Наркотизм как правовая категория. // Право и политика. -2008 . - № 7.

11. У.А. Латыпов. Международное уголовное сотрудничество как механизм обеспечения национальной безопасности // Национальная безопасность / nota bene. -2010 . - № 1 .

12. Летиция Паоли, Элико Циклаури-Ламмих. Основные аспекты политики России по противодействию незаконному обороту и употреблению наркотиков. // Право и политика. - 2002. - № 2.

13. А. В. Маслова, С. В. Тихоненко. Международная специальная операция как инструмент борьбы с контрабандой наркотиков. // Право и политика. - 2002. - № 2.

14. Д.В. Бахарев, А.В. Жигалова. Проблемы и перспективы организации противодействия незаконному обороту наркотиков в заведениях досуга и отдыха молодежи (опыт межрегионального исследования) // Национальная безопасность / nota bene. - 2009. - № 5.

15. В.В. Кухарук. Незаконный оборот психоактивных веществ и нетрадиционные способы воздействия на психические функции человека: проблемы уголовно-правового регулирования // Право и политика. -2009 . - № 10.

16. А.Ф. Галузин. О наркотизме и нарколоббизме в теории и практике обеспечения безопасности личности, общества (государства). // Право и политика. - 2007. - № 11.

17. М. Хасан. Проблемы международного сотрудничества по борьбе с наркотиками. // Право и политика. - 2006. - № 8

\section{References (transliteration):}

1. Gabiani A.A. No krayu propasti: narkomaniya i narkomany. M.: Mysl', 1990. S. 88, 89

2. L.I. Fusu. Epidemiologicheskie determinanty razvitiya depressivnogo sindroma u lits, zloupotreblyayushchikh narkoticheskimi veshchestvami // Psikhologiya i Psikhotekhnika. - 2013. - № 6. - S. 104107. DOI: 10.7256/2070-8955.2013.6.6985.

3. Lopatina V.V.. Problemy narkotrafika i legalizatsiya narkotikov v Latinskoi Amerike // Mezhdunarodnye otnosheniya. - 2014. - № 1. - S. 104-107. DOI: 10.7256/2305-560X.2014.1.10242.

4. Chirkov D.K., Evlanova O.A., Koimshidi G.F.. Regional'nye osobennosti i razlichiya prestuplenii v sfere nezakonnogo oborota narkotikov // Natsional'naya bezopasnost' / nota bene. - 2013. - № 6. S. 104-107. DOI: 10.7256/2073-8560.2013.6.9679.

5. Ya.S. Karpov. Analogi i proizvodnye narkoticheskikh sredstv i psikhotropnykh veshchestv: aktual'nye problemy opredeleniya, kvalifikatsii i kontrolya // Natsional'naya bezopasnost' / nota bene. - 2012. № 5. - S. 104-107.

6. E. A. Popov. Osobennosti deyatel'nosti sluzhb, svyazannykh s protivodeistviem narkoticheskoi zavisimosti naseleniya // Pravo i politika. - 2012. - № 10. - S. 104-107.

7. E. A. Popov. Kriminologicheskie i sotsial'nye osobennosti mekhanizma protivodeistviya narkotizatsii // Pravo i politika. - 2012. - № 6. - S. 104-107.

8. T. V. Kerimova. Risk sostoyaniya zavisimosti // Politika i Obshchestvo. - 2012. - № 2. - S. 104-107. 
9. G. M. Gornichar. Probely v stat'e 230 UK RF: sklonenie k potrebleniyu narkoticheskikh sredstv ili psikhotropnykh veshchestv // Pravo i politika. - 2011. - № 9. - S. 104-107.

10. V.V. Loshkarev. Narkotizm kak pravovaya kategoriya. // Pravo i politika. - 2008. - № 7.

11. U.A. Latypov. Mezhdunarodnoe ugolovnoe sotrudnichestvo kak mekhanizm obespecheniya natsional'noi bezopasnosti // Natsional'naya bezopasnost' / nota bene. - 2010. - № 1 .

12. Letitsiya Paoli, Eliko Tsiklauri-Lammikh. Osnovnye aspekty politiki Rossii po protivodeistviyu nezakonnomu oborotu i upotrebleniyu narkotikov. // Pravo i politika. - 2002. - № 2.

13. A. V. Maslova, S. V. Tikhonenko. Mezhdunarodnaya spetsial'naya operatsiya kak instrument bor'by s kontrabandoi narkotikov. // Pravo i politika. - 2002. - № 2.

14. D.V. Bakharev, A.V. Zhigalova. Problemy i perspektivy organizatsii protivodeistviya nezakonnomu oborotu narkotikov v zavedeniyakh dosuga i otdykha molodezhi (opyt mezhregional'nogo issledovaniya) // Natsional'naya bezopasnost' / nota bene. - 2009. - № 5.

15. V.V. Kukharuk. Nezakonnyi oborot psikhoaktivnykh veshchestv i netraditsionnye sposoby vozdeistviya na psikhicheskie funktsii cheloveka: problemy ugolovno-pravovogo regulirovaniya // Pravo i politika. - 2009. - № 10 .

16. A.F. Galuzin. O narkotizme i narkolobbizme v teorii i praktike obespecheniya bezopasnosti lichnosti, obshchestva (gosudarstva). // Pravo i politika. - 2007. - № 11.

17. M. Khasan. Problemy mezhdunarodnogo sotrudnichestva po bor'be s narkotikami. // Pravo i politika. -2006 . - № 8 